\title{
Alcohol and Soviet Society
}

If, in a nation where comprehensive statistics on social problems are rarely if ever published, legislative action and press attention to such problems may be taken as an indication of the seriousness with which they are regarded, then the Soviet Union's alcohol problem is serious indeed. On April 8, 1967, the Supreme Soviet of the RSFSR approved a decree, On Compulsory Treatment and Labor Re-education of Habitual Drunkards (Alcoholics). ${ }^{1}$ This decree, which went into effect on September 1 of the same year, provides for one to two-year terms in special "treatment-labor" medical institutions for excessive drinkers who violate "labor discipline, public order, and the rules of the socialist community." The new institutions were subordinated not to the Ministry of Health but to the RSFSR Ministry for the Preservation of Public Order (MOOP, now renamed MVD). While it contained a number of significant departures from earlier legislation, the decree's most important point was its "preventive" emphasis. Previously an offending drunkard had to be on trial for a crime in a people's court before proceedings for compulsory treatment could be instituted. But the need to reach the drunkard before he committed a serious offense had been argued over recent years in the press and in Soviet legal periodicals.

In 1969 two signed articles by Soviet scholars long concerned with crime and alcoholism were published. On March 29 Pravda published a contribution by Professor Iu. M. Tkachevsky of the criminal law department at Moscow State University, a large part of which was devoted to a proposal for the establishment of a "public" organization to continue the efforts of the All-Union Council of Antialcohol Societies, which ceased to function in 1930.2

1. Vedomosti Verkhovnogo Soveta RSFSR, 1967, no. 15 (Apr. 13), pp. 329-30 (translated in Current Digest of the Soviet Press, May 3, 1967, p. 11). The two categories - "habitual drunkard" and alcoholic-in the statute's title are not clearly distinguished in Soviet writings. A rough distinction between "drunkenness" as a behavioral concept relevant to public-order concerns and "alcoholism" as a medical concept can be made, but it obscures the reluctance of Soviet writers to call alcoholism simply a "disease." For our purposes, the terms can be taken as roughly interchangeable and as signifying a person whose involvement with alcohol has seriously impaired his social, economic, or civic functioning.

2. Trans. in CDSP, Apr. 16, 1969, pp. 28-29.

The author wishes to acknowledge the support of the Inter-University Committee on Travel Grants, which made possible a semester of research in the USSR, and of the Center for Russian and East European Studies, University of Michigan. 
Two months later, on May 27, Izvestiia included an article by Professor A. A. Gertsenzon, a veteran criminologist and section head at the All-Union Institute for the Study of the Causes and Elaboration of Preventive Measures of Crime, referring to Tkachevsky's article and strongly favoring the establishment of a new antidrunkenness society. ${ }^{3}$ Gertsenzon complained that the "liquidation" of the earlier antialcohol organization had been "without sufficient reasons." In 1966 the collective volume Alcoholism: The Path to Crime, published under the auspices of the institute with Gertsenzon as responsible editor, had strongly recommended the establishment of such an organization. ${ }^{4}$ However, no action has yet been taken (as of July 1971) to implement these recommendations. ${ }^{5}$

The legislative changes and the more recent calls for organizational innovation indicate a growing concern with the problems of alcoholism and drunkenness and a dissatisfaction with the measures hitherto employed to deal with them. State and party bodies have generally shared responsibility for conducting "antialcohol propaganda" with medical personnel on the local level. Low priority has apparently been assigned to the task, and the propaganda itself has been of low quality. The proposed antialcohol society would evidently assume these functions. In addition, there is evidence that the decision to broaden the application of compulsory treatment in institutions under police management accords with a feeling that psychiatric hospitals do little for drunkards who are also "hooligans" and that a system which requires inmates to work (and in which deductions are made from their earnings to cover costs of treatment and maintenance-such "care" is not free) is more suited to the treatment of persons who are held to be basically to blame for their afflictions.

Quantitative data on alcohol consumption per capita in the USSR are sketchy and dated, but of interest nonetheless. In 1956 the Bol'shaia meditsinskaia entsiklopediia reported an annual consumption rate of 1.85 liters of absolute alcohol per capita for $1948-500^{6}$ This placed the USSR last among thirteen listed nations, well below France's figure of 21.5 liters per capita, and the 5.1 for the United States. While much is made of the fact that this represents a decline from a consumption rate of 3.41 liters per capita during the years 1906-10 in European Russia, reduction in consumption has

3. Trans. in $C D S P$, June 11,1969 , pp. 22-23.

4. Alkogolizm: Put' k prestupleniiu (Moscow, 1966). This volume, it seems probable, was the product of a state-party "commission" to the institute to produce a study to serve as a potential aid to policy-making.

5. Gertsenzon, in a conversation with the author in June 1969, shortly after his Izvestiia article had appeared, professed not to know whether the foundation of such a society was to be expected in the near future.

6. Bol'shaia meditsinskaia entsiklopediia, vol. 1 (Moscow, 1956), col. 727. These, unfortunately, were the most recent figures available to the author. 
been a general trend. The USSR dropped from twelfth to thirteenth place in per capita consumption between 1906-10 and 1948-50.7 (All of the countries reporting in both the 1906-10 and 1948-50 periods underwent a decline: in Italy an even greater proportional reduction took place, from 18.29 liters to 9.2.) Referring to the "high" consumption in the 1906-10 period, Soviet sources also note that in consumption of strong liquor (vodka), Russia was fifth among countries reporting. ${ }^{8}$

For more recent years, indirect evidence indicates an increase in consumption. The 1965 production figures for ethyl alcohol (assuming that about 40 percent of such production is used in the manufacture of 40 percent alcohol beverages and the rest devoted to industrial use) indicate that in that year there were approximately ten liters of such strong liquor available per capita for a population of 231 million. ${ }^{9}$ This represents a significant increase over 1950 when slightly more than four liters were available per capita. ${ }^{10}$ Although the estimates do not take account of probable increases in export and industrial use, they are impressive. It should be noted that these figures do not include wine and beer, and also that given the high concentration of drinking among adolescent and adult males the average annual intake of the drinker is bound to be higher. This hypothesized growth finds some reflection in a 1966 observation that over the course of ten years in Moscow Oblast, sales of alcoholic beverages had grown 2.2 times, and vodka sales had exceeded the growth rate of other alcoholic beverages by $15-20$ percent. ${ }^{11}$

The persistence of illegal distilling (samogonovarenie) increases the need to qualify available consumption figures. A study of rural areas in the RSFSR in 1927 found that the rural population consumed an average of 7.5 liters of samogon per capita each year, and that 80 percent of their alcohol consumption was in this form. A more recent study in the late 1950s, though it gave no

7. Data for 1906-10 are from Alkogolizm: Put' k prestupleniiu, p. 95. The full figures, expressed in terms of liters of absolute alcohol per capita per year, are as follows: For 1906-10: (1) France, 22.93 liters, (2) Italy, 18.29, (3) Spain, 14.02, (4) Greece, 13.87, (5) Switzerland, 13.71, (6) Belgium, 10.58, (7) England, 9.67, (8) Germany, 7.56, (9) United States, 6.89, (10) Denmark, 6.82, (11) Sweden, 4.33, (12) Russia (European), 3.41, (13) Norway, 2.63, and (14) Finland, 1.54.

For 1948-50: (1) France, 21.5, (2) Spain, 10.0, (3) Italy, 9.2, (4) Switzerland, 9.0, (5) Belgium, 6.5, (6) Great Britain, 6.0, (7) United States, 5.1, (8) West Germany, 3.75 , (9) Sweden, 3.6, (10) Denmark, 2.85, (11) Norway, 2.2, (12) Holland, 2.0, and (13) the USSR, 1.85.

8. Alkogolizm: Put'k prestupleniiu, p. 95.

9. See Y. Mironenko, "The Fight Against Alcoholism in the USSR," Bulletin of the Institute for the Study of the USSR (Munich), 14, no. 9 (1967): 28.

10. Based on an estimated 1950 population of $178,547,000$. See Warren Eason, "Population Changes," in Allen Kassof, ed., Prospects for Soviet Society (New York, 1968), p. 220.

11. Alkogolizm: Put' k prestupleniiu, p. 84. 
data on how widespread the offense was, found it enduring. Small-scale production (up to two liters) accounted for 37.7 percent of the offenders, while 5.3 percent were apprehended after producing over ten liters. Of all offenders, 78.5 percent had used "special apparatus" for the distilling. ${ }^{12}$

This article addresses itself first to the drinking practices and attitudes widespread in the USSR-what may be called a Russian "drinking culture." The adjective "Russian" is advisable in this context. The republics of the Caucasus and the Muslim areas of Central Asia differ in historical background, attitudes toward alcohol, and types of alcoholic beverages most frequently consumed. There is a lack of Soviet data on contemporary ethnic differences in this regard, and therefore what is said of the European areas cannot be extended without modification to Central Asia, the Caucasus, and areas where non-Slavic populations are concentrated. ${ }^{13}$ Subsequent sections deal with the perceived social costs of alcoholism, the gap between "official" and popular attitudes, and the present state and future prospects of the Soviet "struggle" with problems of excessive drinking.

\section{The "Drinking Culture"}

One of the most striking elements in Russian drinking behavior is the multiplicity of occasions with which drinking is associated. ${ }^{14}$ In the sphere of popular, "unofficial" values alcohol is a virtually indispensable adjunct to many events, and is a direct refuge from tension or pain-creating situations. Persistent complaints in the press about the practice of payday drinking bouts by factory workers, which often end in brawls with coworkers and family "scandals" when the intoxicated worker returns home minus some of his

12. Ibid., pp. 21-23.

13. By no means, however, need large areas of the USSR be automatically excluded from the picture which emerges. Substantial Russian-Ukrainian migration to Central Asia (and to some degree the Caucasus), especially to larger cities, means "transportation" of the drinking culture as well. In areas where Islam (with its prohibition of alcohol) has been relatively weak, for example in Kazakhstan, native populations may not differ so greatly from Russian patterns. Even the traditionally stronger Muslim areas, such as Uzbekistan, do not show the abstinent orientation that characterizes much of Arabic Islam.

The Caucasus (especially Georgia) shows different drinking patterns, concentrating on wines and cognacs. Yet much of the surface association of drinking with masculinity seems evident here too, as in the Russian case. If the Russian drinking culture resembles in some ways the Irish variant, Georgian attitudes and patterns may resemble, in general and in their pathological aspects, the French. These suggestions are only tentative, and their confirmation must await data presently unavailable.

14. "People drink when they meet, when they take leave of each other; to quiet their hunger when they are hungry, to stimulate their appetite when they are satisfied. They drink to get warm, when it is cold, to cool off when it is hot. They drink when they are drowsy, to wake up, and when they are wakeful, to bring on sleep." V. M. Banshchikov, Alkogolizm i ego vred dlia sdorov'ia cheloveka (Moscow, 1958), p. 5. 
wages, indicate one of the most frequent occasions for "convivial" drinking. ${ }^{15}$ V. E. Rozhnov, in a book addressed to members of the armed forces, enumerates some other occasions:

One bought a pair of shoes-he has to "wash it off," he won on a lottery ticket-he also must "wash it off," he got an apartment or a bonus-how can he not "wash it off"? Is a child born, did someone die, did there occur some sort of misfortune, or, on the other hand, some happiness, is someone going away on vacation, or returning from a health resort-many begin to drink because of these "occasions."

Important events in family life provide another stimulus for the sort of excesses deplored by those who write about the problem of drunkenness. Pravda recently noted on two separate occasions the large amount of money spent, and workdays lost, because of large wedding celebrations on collective farms, which include "drinking bouts lasting many days and involving large numbers of people and in which . . . an unhealthy competition in plying the guests with liquor has been conducted."17 Thus it is no surprise that the Soviet nondrinker often finds himself at odds with the rest of the company in social situations. The teetotaler, or the person who is unshakable in his resolve to drink only moderately, does so at the risk of offending his companions, of being considered something less than a "real man." Obstinate refusal to drink under these circumstances is often regarded as a real insult, as well as "peculiar" behavior. ${ }^{18}$ Strenuous also is the route of the reformed drinker, whose "friends and relatives" often provide the push to send him "off the wagon." ${ }^{19}$ One of the leading Soviet medical specialists in alcoholic problems notes that in one survey of alcoholic "backsliders" 42.2 percent of the cases were attributable to the influence of companions or relatives who persuaded the patient to have a drink. ${ }^{20}$

Drinking remains largely a male activity (cases of alcoholism are "still encountered" among women, but "very seldom"), ${ }^{21}$ and "socialization" in p. 29).

15. See, for example, Izvestiia, Mar. 2, 1958, p. 4 (trans. in CDSP, Apr. 9, 1958,

16. V. E. Rozhnov, Po sledam zelenogo zmiia (Moscow, 1969), pp. 35-36.

17. Pravda, Apr. 6, 1969, p. 3 (trans. in CDSP, Apr. 23, 1969, p. 19). See also Pravda, Jan. 13, 1969, p. 3 (trans. in CDSP, Jan. 29, 1969, pp. 18-19).

18. Rozhnov, Po sledam zelenogo zmiia, p. 36. See also Iu. M. Tkachevsky, Prestupnost' i alkogolizm (Moscow, 1966), p. 8, and Iu. Levin, "O vrede alkogolia," in $Z$ a kommunisticheskii byt (Leningrad, 1963), p. 243.

19. Levin, "O vrede alkogolia," p. 254.

20. B. M. Segal, Alkogolizm: Klinicheskie, sotsial'no-psikhologicheskie $\boldsymbol{i}$ biologicheskie problemy (Moscow, 1967), p. 521.

21. L. A. Bogdanovich, Zhizn' nachinaetsia segodnia (Moscow, 1967), p. 56; Rozhnov, Po sledam zelenogo zmiia, p. 60. Whether this pattern is changing or not is hard to ascertain. In the United States the past century has seen a reduction in the male-female 
drinking practices often begins early. A father who, over his wife's objections, gives his five-year-old son a glass of wine argues, "let him get used to it . . . he's got to be a real man." 22 Teenage factory workers soon become accustomed to payday drinking with "veterans" in their shops. A refusal to participate is often viewed as "bad form." The intoxication which often follows the "workers' baptism" accompanying the first payday occasionally lands the youth in the arms of the militia. ${ }^{23}$

Soviet journalists and pamphleteers are content to denounce these phenomena as "survivals of the past," but they in fact point to the existence of a Russian "drinking culture"-an historically deep-rooted complex of attitudes and practices involving the use of alcohol, which also has its roots in the conditions of contemporary Soviet life. Studies of the drinking patterns of other ethnic groups have shown the intricate relations of norms and values concerning alcohol use, and the incidence of drunkenness and alcoholism. ${ }^{24}$ Drinking, when closely linked with religious ritual, as among Jews, or when viewed as an integral part of meals, as the consumption of wine is among Italians, rarely takes on pathological dimensions, even when the population shows a high annual per capita consumption rate. The relatively high rate of alcohol pathology among the Irish, on the other hand, has been explained, at least in part, on the basis of the absence of social contexts for drinking that integrate it into religious or family life, along with the presence of the idea of drinking as a masculine activity, something which affirms one's manhood and solidarity with one's fellows, and as an approved means of increasing one's gaiety or deadening one's sorrow. Such may be true as well of the Russian case.

Research in the West has pointed to "dependency conflicts" in the male life cycle as important elements in the etiology of alcoholism..$^{25}$ For a variety of reasons "dependency needs" (for maternal warmth, response, nourishment, protection) acutely felt by male children may be inconsistently and sporadically

alcoholic ratio from around 20:1 to 5:1. The social forces which have increased women's contacts and activities outside the household in the USSR, reducing the "distance" between male and female roles, may be having the same effect. Young urban women especially seem to find few prohibitions against their drinking, although drunkenness is not accepted as tolerantly in them as it is in men. The Soviet female alcoholic may also have a greater chance of escaping diagnosis than her American counterpart, since she is more likely to do her drinking in private.

22. Bogdanovich, Zhizn' nachinaetsia segodnia, p. 49.

23. See the instance in Izvestiia, Feb. 25, 1964, p. 4.

24. See Robert F. Bales, "Attitudes Toward Drinking in the Irish Culture," and Charles R. Snyder, "Culture and Jewish Sobriety: The Ingroup-Outgroup Factor," both in David J. Pittman and Charles R. Snyder, eds., Society, Culture, and Drinking Patterns (New York, 1962).

25. See, for example, William McCord and Joan McCord, Origins of Alcoholism (Stanford, 1960), esp. pp. 54-72. 
fulfilled in the family setting. Although "legitimate" for young children, such needs conflict with the "model" image of the adult male-in the USSR as well as in the West-as a mature, productive, and independent adult, whose duties consist largely of satisfying the needs of wife and children. For those whose childhood dependency needs are satisfied, the transition to the adult male role is relatively easy. For the unsatisfied the transition is fraught with difficulties. Consciously or subconsciously, dependency needs, now regarded as "illegitimate" and "feminine," are suppressed, and are disavowed through adoption of decisively "masculine" behavior patterns-sometimes extremely aggressive behavior, and sometimes, where the culture makes it available, heavy drinking, a "man's prerogative." The warmth and solace that many find in drinking may provide a means, if a dangerous one, of satisfying the dependency needs still felt.

Although Soviet researches are not conducted in this perspective, it merits attention. Problems of divorce, desertion, parental conflict, and the like are widespread in Soviet as in American society, and presumably have an important impact on parental abilities to satisfy dependency needs. Given the existence of some segment of the male population whose childhood needs remain unfulfilled, and the demands on them, as on other Soviet men, to provide support for dependents in much the same manner as in the West-to be, within the scope of their jobs, "achievers"-it is not difficult to imagine some seeking the refuge that a manhood-affirming drinking culture offers.

In addition, heavy drinking can be viewed as an "escape" mechanism. Crowded housing, low wages, high-priced consumer goods, and other problems result in a certain level of dissatisfaction, especially among the working classes who feel the burden most directly. Frustrations over limited opportunities for upward mobility as social class boundaries become harder to cross and the feeling of being "stuck" in uninteresting jobs add to the stress. ${ }^{26}$ But escape mechanisms are not in abundance in Soviet society for those who would seek them. Emigration to lands where perceived opportunities are greater is rarely an alternative. Nor do involvement in organized religion and the adoption of a perspective minimizing the significance of worldly problems seem to be viable solutions for many adult males, even leaving aside the issue of governmental atheism. Alcohol, however, is available. Its use to cope with stress is culturally

26. Whether the predominance of working-class alcoholics and drunkards evident in Soviet discussions reflects the actual situation, or middle-class observer bias, is hard to determine. A drunken worker on the factory floor is easier to detect than an executive in the early phases of alcoholism, who can more easily separate his drinking and his work. The latter has more to "lose" and thus is probably less likely to appear in public intoxicated and become a police statistic. Soviet writings are liberally sprinkled with stories of men who have fallen from responsible positions to disgrace because of their drinking, but most of the attention is still concentrated on lower-class drunkards. 
permissible. It can provide the solitary drinker with the oblivion which is the most radical temporary form of escape. Heavy drinking in convivial groups can provide a sense of camaraderie, of effortless interaction with others, which many find lacking in modern urban society, whether Soviet or not.

These are some suggestions concerning the causes of Soviet alcoholism. To determine the relative significance of a drinking culture, dependency conflicts, and the demand for escape mechanisms is a knotty methodological problem, as well as one for which we lack the requisite data. It can only be said that each of the factors discussed is bound to be important, and that none can be ignored.

\section{The Social Costs of Alcohol}

Soviet calculations of the social costs of drinking fall into three broad categories: public order (delinquency and crime), the economy (industrial accidents, waste, etc.), and what might be loosely termed the "quality of life" -the effects of alcohol abuse on family life and leisure. ${ }^{27}$

Scattered statistics report a high rate of violent crimes committed "in an unsober state." For the nation as a whole, statements are made that "70 percent of all crimes" and "more than 80 percent of all hooligan acts" are committed by intoxicated persons. ${ }^{28}$ Nonviolent property crimes are often traced to alcohol, notably embezzlement and theft by employees who need money for liquor.$^{29}$ In another vein, the illegal distilling of alcohol is itself a major category of crime in some areas. Data from a study of crime for the years 1953-63 in a district in Belorussia show that one out of three offenders "brought to criminal responsibility" was engaged in illegal distilling. ${ }^{30}$

The relatively unregulated sale of alcohol to minors, and the social pressures on (especially) the less-educated young workers to "be a man" and drink, have given rise to concern over the connection between alcohol and delinquency.

27. "The consumption of alcoholic drinks in our country . . causes harm to the health of Soviet citizens, gives rise to disability, shortens the life-span, brings disorganization into personal, family, and social life, reduces labor productivity, and serves as a cause of instances of hooliganism and crime" (Levin, "O vrede alkogolia," p. 228).

28. Izvestiia, Mar. 2, 1958, p. 4 (trans. in CDSP, Apr. 9, 1958, p. 29); V. M. Banshchikov, Alkogolizm i ego vred, p. 32.

29. Ia. E Gurvich, P'ianstvo gubit cheloveka, nanosit vred obshchestru (Moscow, 1958), p. 30 .

30. N. N. Kondrashkov, "Analiz raionnoi statistiki prestupnosti," Voprosy preduprezhdeniia prestupnosti, 1966, no. 4, p. 44. The economic aspect of the problem is evident in complaints of "shrinkage" of grain reserves and the loss of working hours from laborers engaged in samogonovarenie. Cases are reported of collusion between collective and state farm chairmen and the distillers-grain is "officially" designated for distilling, and those who do the distilling are given labor-day credit for the work. See Alkogolizm: Put $k$ prestupleniiu, pp. 24-25. 
The authors of an article on the subject report that "in the course of talks with 356 youths, held in a labor colony for juveniles, it was found that almost half of them had committed [their] crimes in a state of intoxication, 78 percent admitted that they had continually used alcoholic beverages up to the time of arrest, [and] 33 percent had violated the criminal law with the purpose of getting money for them." 31

The concern over drunkenness as a cause of crime is not usually directed at the person whose intoxication is casual, who "under the influence" does things he would otherwise abhor. Some writers even doubt that such a person exists: "Even in a state of intoxication, a person does not do anything that is utterly foreign to his nature; possessed of high and strong moral principles he will not, even under the influence of alcohol, commit an immoral act." 32 The major worry is rather that the long-term "degradation" of the personality that results from habitual heavy drinking leaves the drinker susceptible to immorality and crime. ${ }^{33}$ Some support for this view is found in a research study which showed that only 17 percent of the persons studied who had committed crimes while intoxicated did not have a long alcoholic period before their offense. The other 83 percent were "chronic alcoholics." 34

Although comprehensive figures on the number of man-hours lost and injuries sustained on the job because of drunkenness are not available, the indications are that alcohol plays an important role in these areas. Nedelia reports that a "study" in Gorky showed violations of labor discipline to be connected with drunkenness "in sixty-six instances out of a hundred." 35 In March 1964 the party secretary of a lathe-building plant complained that workers' and technicians' drinking sprees had caused the loss of over a thousand man-hours-"enough for six new lathes." to drink at lunch time are continually warned that anything but complete sobriety in operating large machines can lead to serious injury, ${ }^{37}$ and antialcohol writers also strive to convince the many who feel they "work better"

31. L. Vaisberg and Sh. Taibakova, "Alkogolizm i prestupnost' nesovershennoletnikh," in U. Dzhekebaev, ed., Voprosy bor'by s prestupnost'iu nesovershennoletnikh (Alma-Ata, $1968)$, p. 101. In this connection, many Soviet jurists have argued that adults, when responsible for the state of drunkenness in which a minor commits an offense, should be made to bear equal legal penalties. See, for example, A. B. Sakharov, "Alkogol' i prestupnost' nesovershennoletnikh," Sovetskaia iustitsiia, 1965, no. 16, pp. 22-23.

32. A. B. Sakharov, O lichnosti prestupnika i prichinakh prestupnosti v SSSR (Moscow, 1961), p. 232.

33. Ibid., p. 235.

34. Alkogolizm: Put' $k$ prestupleniiu, p. 6, citing Problemy sudebnoi psikhiatrii, 9 (1961) : 372.

35. Nedelia, July 24-30, 1966, p. 2.

36. Sovetskaia Rossiia, Mar. 26, 1964, p. 4.

37. Rozhnov, Po sledam zelenogo zmiia, p. 97. 
after a drink that their sense of increased capability is not matched by any increase in productivity, but leads often to a higher rate of spoilage. ${ }^{38}$

The economic impact of rural illegal distilling is also seriously felt. The use of sugar, grain, beets, and potatoes in the production of samogon exacerbates agricultural problems, as does the loss of workdays on collective farms because of overindulgence. ${ }^{39}$

A host of family problems are attributed to excessive drinking by husbands and fathers. Tkachevsky claims that 40 percent of all divorces are caused by the drunkenness of one of the spouses (see note 2). Mistreatment of children is another major offense. Five years ago, a letter from a twelve-year-old whose father's habitual drunkenness had made home life unbearable was the starting point of a "readers' discussion" in Izvestiia which continued for many issues. ${ }^{40}$

As Soviet writers become less reticent to discuss sexual matters, they find that alcohol is connected with many problems in this area. Prolonged impotence from habitual heavy drinking is cited as a source of marital tensions, ${ }^{41}$ and a noted Soviet clinician cites his own researches to show that husbands who drink heavily become "gross" in their approach to intercourse and decrease the pleasure of both partners. ${ }^{42}$ The evils of "casual" sex under the influence of alcohol are stressed for youth ;3 ${ }^{43}$ and Rozhnov, in his book intended mainly for members of the armed forces, ominously cites the words of a Soviet venereologist, 90 percent of whose syphilis and 95 percent of whose gonorrhea patients contracted the diseases while drunk. ${ }^{44}$

The increase in leisure time available to many in the Soviet Union is accompanied by concern in some quarters that the time will be used "unprofitably." 45 Among unprofitable uses, drinking is considered a major one. After the establishment of the five-day workweek, weekend liquor sales were reported to have increased as much as 25 percent in Moscow. ${ }^{46}$ Even those who engage in "healthy" athletic activity, such as swimming, may endanger their lives by

38. Banshchikov, Alkogolizm i ego vred, p. 8.

39. Some of the recent history of the "intensified struggle" with illegal manufacture of alcohol is reflected in the 1960 and 1961 RSFSR decrees on the subject. See CDSP, Mar. 2, 1960, p. 21, and June 7, 1961, p. 22.

40. The original letter appeared in Izvestiia, June 17, 1965, p. 3 (trans. in CDSP, July 28, 1965, p. 10) ; "follow-up" letters were printed in CDSP, July 28, 1965, pp. 10-17.

41. See, for example, Bogdanovich, Zhizn' nachinaetsia segodnia, pp. 52-56, and Rozhnov, Po sledam zelenogo zmiia, pp. 56-57.

42. The most complete discussion of this topic is in Segal, Alkogolizm, pp. 126-32.

43. See Bogdanovich, Zhizn' nachinaetsia segodnia, pp. 17-22, for an account of teenage drinking parties.

44. Rozhnov, Po sledam zelenogo zmiia, p. 61.

45. For a brief review of some of the problems and patterns of Soviet leisure, see Paul Hollander, "The Uses of Leisure," Survey, July 1966, pp. 40-50.

46. Literaturnaia gazeta, Dec. 13, 1967, p. 12 (trans. in CDSP, Jan. 3, 1968, pp. 3-4). 
combining it with drinking-Tkachevsky notes that 63 percent of all individuals in Moscow Oblast who drowned in 1968 (which should include a large number of swimmers) were intoxicated (see note 2 ). The peril to sports careers from drinking is detailed in a number of Soviet books and pamphlets, with stories of the moral and physical downfall of athletes who develop a liking for the "green serpent." 47

\section{Official Values and Popular Opinion}

The gap between official attitudes toward drinking and "private" or popular opinion seems to be a wide one. ${ }^{48}$ The regime's values form the basis for a scale of evaluation in which a citizen is found "good" insofar as he embodies the qualities of the "new Soviet man"-sober, methodical, industrious, and committed to productive work and participation in the "public life" of Soviet society. A statement such as the following one can only be understood as an exhortation in the "indicative-imperative" style of Soviet writing: "Soviet man, the builder of the new Communist society, the sovereign ruler of his own native land, has firm confidence in tomorrow, and does not need drunkenness." 49 The attitudes which cause so many Soviet citizens to deviate from this ideal are worth attention. Beyond the fact that most men drink, it is clear that drunkenness is viewed by many without any particular feelings of censure or disgust. A pamphlet writer complains that the struggle with alcoholism would enjoy greater success "if there were not connivance and an indifferent attitude toward it on the part of the public." 50 The belief that alcohol is an indispensable element in the celebration of family events and holidays is seen as a major cause of alcoholism. One Soviet treatise cites studies indicating that in a large majority of cases the family backgrounds of alcoholics and drunkards revealed tolerance or acceptance of drunkenness. ${ }^{51}$

Certain "widespread beliefs" are another target of the writers and propagandists-among them, that alcohol is useful and beneficial as a medicine, and that although volka may indeed be dangerous when drunk continually in large

47. See, for example, Rozhnov, Po sledam zelenogo zmiia, pp. 106-16, and Bogdanovich, Zhizn' nachinaetsia segodnia, pp. 23-31.

48. "There are, unfortunately, not a few people who consider the customs of the 'pub' normal, generally accepted, almost an everyday thing, but temperance-an abnormal exception. 'Everyone drinks alcohol,' these people say in the discussions arising after lectures on the struggle with alcoholism" (Levin, "O vrede alkogolia," p. 249).

49. Gurvich, $P^{\prime}$ ianstvo gubit cheloveka, p. 11.

50. Tkachevsky, Prestupnost' $i$ alkogolizm, note 9.

51. See Segal, Alkogolizm, pp. 47-48 and 298. Without control groups, the significance of such findings cannot be properly assessed. An American study, with controls, showed no significant relationship between father's or mother's approval (or disapproval) of drinking and the later alcoholism of their male offspring (see McCord and McCord, Origins of Alcoholism, p. 42). 
quantities, weaker drinks such as wine and beer may be consumed without fear. ${ }^{62}$ Party and state officials are also faced with economic objections to their efforts to discourage drunkenness. Appeals to plant and office management to "do something" about the drunkenness of workers off the job brings the response that skilled workers are at a premium, and that even "measures" short of firing that could be taken against an offender may cause him to quit. An official complained that of "several thousand" notifications about employees' public drunkenness in Khabarovsk, only 634 were answered with a reply to the militia that "measures" had been taken. ${ }^{.3}$

In attempting to convince the public at large of the evils of drinking, the regime encounters at least three major problems. First, the web of popular attitudes that define drinking as "manly" and a necessary adjunct to conviviality is hard to penetrate. Such attitudes, as one doctor notes, "are extremely hard to overcome in an adult, especially when the majority of those around him also use alcoholic beverages." ${ }^{44}$ Nor has antialcohol persuasion linked itself effectively to other positive values in the drinker's consciousness. Rhetorical appeals on the basis of "patriotism" and civic dignity have scant effect. Warnings about the dangers of illness to the drinker and genetic harm to his offspring are closer to his personal concerns, but are often met with disbelief that such could happen to him (these "scare" tactics have generally not been successful).$^{.5}$ Appeals to the drinker not to jeopardize the happiness of his family conflict with his conviction that at home, at least, he should be allowed the mode of relaxation he wishes.

The second major difficulty encountered in attempts to convince the public of the dangers of drinking is the inconsistent treatment of the subject in various media and in lectures. Most antialcohol tracts are completely against the use of alcohol, but articles in the press often make a distinction between beer and wine on the one hand and stronger drink on the other-thereby, in the minds of critics, encouraging the use of the former. In view of the counterproductive experience of both the Russian Empire and the Soviet state with "dry laws," prohibition is rejected as a solution. ${ }^{56}$ Yet such a refusal may be somep. 244.

52. Rozhnov, Po sledam zelenogo zmiia, pp. 23, 25, and Levin, "O vrede alkogolia,"

53. Izvestiia, July 14, 1965, p. 4.

54. Segal, Alkogolizm, p. 546.

55. "The arousal of fears, implied warnings, or threats as to what will happen if one drinks too much have been noted to provoke avoidance reactions towards further propaganda. There also seems to be an unwillingness of audiences to particularize such propaganda. This is very apt to be true if the educational materials are pointed to alcoholism as an end result of drinking" (Edwin M. Lemert, "Alcohol, Values and Social Control," in Pittman and Snyder, eds., Society, Culture, and Drinking Patterns, p. 563).

56. "Alkogolizm," Bol'shaia meditsinskaia entsiklopediia, vol. 1, col. 734; Levin, "O vrede alkogolia," p. 246; Segal, Alkogolizm, p. 542. 
what hard for Soviet citizens, accustomed to government intervention in many aspects of "private" life, to comprehend. "If," asked an occasional drinker's wife in a letter to a Soviet editor, "alcohol is so bad, why isn't it prohibited?"57 Proalcohol messages in the entertainment media also cause concern. Cinema heroes are frequently criticized for heavy drinking on the screen and the impression of enjoyment they convey. ${ }^{58}$ Even Komsomol'skaia pravda, in a discussion of proposed regulations to curtail holiday drinking, turned them down on the grounds that it would be "inconceivable" to thus "emasculate" celebrations. ${ }^{59}$

The third obstacle antialcohol forces face lies in the characteristics of the "target" audience. Persons with drinking problems are frequently said to be those who have "little culture," little formal education, and relatively unskilled jobs. Many give "boredom" as a reason for their drinking. To the degree that this is true, ${ }^{60}$ these "escapist" drinkers are unlikely to pay much attention to antialcohol messages, or, for that matter, any other exhortations from official sources.

\section{Weapons in "The Struggle"}

In pressing the fight against drunkenness and alcoholism, the state has "armaments" roughly divisible into four categories: (1) antialcohol propaganda, (2) the mobilization of "public" pressures, (3) compulsory treatment, and (4) measures that are primarily medical. (The last category will not be discussed in detail here.) ${ }^{61}$

Perhaps the most interesting thing about the antialcohol propaganda presented in the Soviet media and lectures is the dissatisfaction with it, which can be expressed in two not wholly consistent complaints: it is largely ineffec-

57. The economics of the present state monopoly on alcohol, as well as the desire to avoid "bourgeois sanctimoniousness," probably provide the answer. The income from alcohol is large, and expenditures absorb much of the population's buying power.

58. See note 2, and Izvestiia, June 27, 1965, p. 6; Izvestiia, July 9, 1958, p. 3 (trans. in CDSP, Aug. 13, 1958, pp. 26-27).

59. Komsomol'skaia pravda, Oct. 9, 1965, pp. 2, 4 (trans. in CDSP, Dec. 16, 1964, pp. 16-18).

60. Some writers refer to the severe alcohol problems of the immediate postwar years (see Segal, Alkogolizm, p. 267) when the standard of living hit a low point; others (see note 52), recognizing this, argue that today's drunkards lack the excuses of poverty and deprivation. Although it seems that alcoholism leads to a decline in the standard of living (Segal, p. 105), those studies that have included control groups to test the relationship of income, education, and occupation to drinking habits have been inconclusive (pp. 298-300), mainly because of the difficulty in securing a "representative" control group.

61. For further information see Vera Efron, "The Soviet Approach to Alcoholism," Social Problems, 7, no. 4 (Spring 1960); A. R. King and M. H. Hand, "Observations in Russia on the Alcohol Problem," Quarterly Journal of Studies on Alcohol, 24, no. 4 (December 1963); Segal, Alkogolizm, pp. 460-519. 
tive and unconvincing, and there is not enough of it. The announced objectives of this propaganda are, first, to form public opinion to view drunkenness as an "alien" and harmful phenomenon, and, second, to involve the "public" in the struggle against it. ${ }^{62}$ In concrete form, antialcohol propaganda fluctuates between generalized appeals to the Soviet citizen's personal and social dignity and relatively crude "scare tactics," such as the description, with illustrations, of pathological changes in the stomach and liver from long-term drinking. ${ }^{\text {es }}$ "Case histories," replete with stories of broken families, lost jobs, and ruined lives, are another feature of the propaganda in pamphlets and newspapers. ${ }^{64}$

Some of the standard claims made by propagandists are problematic. Often it is said that moderate drinking leads almost inevitably to heavy drinking. ${ }^{65}$ Many audiences find this hard to believe, and even those specializing in propaganda find themselves complaining about it: " 'Rivers begin from a stream'they repeat, in every way, this favorite proverb. The numerous exceptions to this rule compel one to have doubts about its infallibility. . . . the majority of those who have gotten used to contenting themselves with small doses, despite the 'prognosis,' do not change for the rest of their lives."

Even more debatable is the frequent assertion that heavy drinking has a direct, physical influence on offspring-accounting for the birth of many weakwitted and physically handicapped children. ${ }^{67}$ Only rarely explored is the possibility that the academic and emotional problems of the children of alcoholics are attributable not to direct physical consequences but to early home environments reflecting parental pathologies. ${ }^{68}$

Much of the face-to-face propagandizing in factories, apartment complexes, and the like is done by persons who have no medical knowledge, or by lowerechelon medical workers who may themselves find the content of their message difficult to believe. B. M. Segal, author of the most comprehensive recent Soviet work on alcoholism, notes that the low effectiveness of propaganda in combatting the deep-rooted proalcohol traditions of the population may be partly due to the propagandists' own lack of 'internal convictions of the correctness of their appeal." 69

62. L. V. Orlovsky, "K metodike antialkogol'noi propagandy," in I. I. Lukomsky, ed., Alkogolizm i alkogol'nye psikhozy (Moscow, 1963), p. 418.

63. See, for example, Rozhnov, Po sledam zelenogo zmiia, pp. 39-55.

64. As noted above (note 55), these appeals are not easily "personalized" by individuals. See also Segal, Alkogolizm, p. 545.

65. See, for 'example, L. A. Lerman, "Meditsinskie rabotniki i protivoalkogol'naia propaganda," Sovetskoe zdravookhranenie, 1958, no. 11, p. 4; Banshchikov, Alkogolizm i ego vred, p. 12; and Sovetskaia torgovlia, May 12, 1959, p. 4.

66. Meditsinskaia gazeta, July 16, 1963, p. 2.

67. See Rozhnov, Po sledam zelenogo zmiia, pp. 62-72.

68. An exception is Segal, who notes this possibility and is far from an unqualified acceptance of the "heredity" argument (Alkogolizm, pp. 132-33).

69. Ibid., p. 546. 
Mobilization of the public as a force for the correction and rehabilitation of drunkards presents real problems, and complaints about public apathy are more frequent than praise for their civic-spiritedness in intervening with drunkards. Thus the account which follows of a worker reformed by the censure of his fellow workers probably represents more the ideal than the typical situation:

One day when he appeared in the shop drunk he was put into the "workers' circle." At first Vladimir was cocky.

"I got drunk; so what? I did it with my own money, not yours. What business is it of yours?"

But the workers began to speak, one after another. The "circle" came to life and got excited, and it was as if a refreshing wind were blowing around Vladimir. He began to sober up right before their eyes. His arrogance vanished as if by magic. He began to defend himself, then to make excuses, then to repeat, and finally he broke down and burst into tears. He swore on his honor that he would never do it again, and he has kept his word. He is now on a par with the leading production workers. ${ }^{70}$

On the other side of the coin, management, workers, the Komsomol, and even the militia are criticized for the lack of concern they frequently show in a hands-off attitude toward drunkards. ${ }^{71}$

"Compulsory treatment" and the network of institutions that provide it represent a "tough" approach to alcoholics. As noted earlier, it is aimed at those whose alcohol problems have already made them violators of public orderthough not necessarily criminals. Nonetheless, it seems likely that under the new legislation persons committed who have not been brought to "criminal responsibility" will be living alongside those who are convicted felons. It is instructive that (1) the "treatment-labor profilaktorii" which existed before the new legislation, and the "treatment-labor institutions" to be set up under it, are administered by the MVD, (2) the period of confinement in the RSFSR statute is one to two years, and at least half of the "sentence" must be served before a patient can be released, and (3) attempted escape from these institutions is a criminal offense, for those committed who are not felons as well as those who are. With the exception of the added element of "special medical treatment," the characteristics of these institutions-a "regime" of confinement, "labor re-education," and "political-upbringing work"-sound the same as those of the corrective-labor colonies for criminal offenders. ${ }^{72}$ Since construc-

70. Izvestiia, Aug. 29, 1965, p. 4 (trans. in CDSP, Sept. 22, 1965, pp. 32-33).

71. Sovetskaia Rossiia, Feb. 12, 1958, p. 2 (trans. in CDSP, Apr. 9, 1958, pp. 30-31) ; Gurvich, P'ianstvo gubit cheloveka, p. 16; Banshchikov, Alkogolizm i ego vred, p. 31 ; Gurvich, p. 11.

72. The statute on treatment-labor medical institutions of the MVD remains unpublished, as does the 1961 decree on the internal organization and regulations of cor- 
tion of facilities for the new institutions seems to be lagging, it may be assumed that much, if not most, of "compulsory treatment" is still carried out in the "treatment-labor" divisions of corrective-labor colonies. ${ }^{73}$

Little can be said about the success of compulsory treatment, for not much information has been made public. Segal discusses the relatively positive results of compulsory treatment in the "closed narcological division" of the North Kazakhstan Oblast psychiatric hospital, but has little to say about the newer institutions just getting into operation. ${ }^{74}$ From all indications, the compulsory treatment institutions reflect a punitive attitude toward the alcoholic, which many doctors share with the public-order authorities. But as well as answering the call for a "crackdown," these institutions may also reflect economic considerations. Complaints are still frequently voiced about habitual drunkards who commit themselves voluntarily to psychiatric hospitals for treatment, sometimes as often as once a year, and resume their old habits when released. ${ }^{75}$ They receive their medical care free, do no work in the hospitals, and receive sick-leave pay in addition. A psychoneurologist describes one person in this category:

After drinking up his last kopeks, a drunkard is placed in the comfortable conditions of a psychiatric clinic. ... After a few days of treatment with modern medicines the alcoholic's symptoms of psychic derangement disappear, as a rule, and he is transferred to the category of the so-called "conscious ill." And then a perfectly healthy lug begins literally making fun of people who are really sick. As soon as he is discharged, the drunkard "washes off" his sick leave payments, and everything starts all over again. ${ }^{78}$

It seems probable that many such "lugs" are classifiable as "violators" under the language of the compulsory treatment decree. If so, the state may well regard treatment-labor institutions, where inmates are made to work and deductions are made from their earnings for the cost of their care and maintenance, as a more suitable environment for them than a psychiatric hospital.

One other "front" in the war against drunkenness involves the structure of retail trade in alcohol and the attempts to control drinking by price manipulation and setting limits on times and places for the sale of liquor. By the mid1950s gradual price decreases and increasing income had made vodka cheaper,

rective-labor colonies and prisons. As the former statute presumably details the internal order of those institutions, it may be an indication of the regime's conception of their nature.

73. See the complaints of a group of women from Yaroslavl in Pravda, Mar. 18, 1968, p. 6 (trans. in CDSP, Apr. 1, 1968, p. 24); Segal, Alkogolizm, p. 538.

74. Segal, Alkogolizm, pp. 536-38.

75. Izvestiia, Sept. 5, 1968, p. 5 (trans. in CDSP, Sept. 25, 1968, pp. 25-26).

76. See Izvestiia, Oct. 1, 1968, p. 5 (trans. in CDSP, Oct. 23, 1968, p. 19). 
and the increase in numbers of establishments selling it added to the problem of growing consumption. Administrative regulations in many large cities attempted to limit sales, and by 1961 it was claimed that alcoholic beverages could no longer be purchased in communal dining rooms and snack bars-two major sources. ${ }^{77}$ Violations of these regulations were, however, frequent, and remain so. $^{78}$ Since the sales plans of eating establishments where liquor can be served concentrate on the high-profit items, alcohol is often "pushed" in these places to a degree that draws complaints from those who see the economic forces here as working counterproductively. ${ }^{79}$

It is, in fact, easier to detail the problems encountered in enforcing such regulations than to specify their provisions, since most of these regulations are promulgated on a local (city) level and are "administrative" in nature. Writing in Izvestiia in 1958, a doctor praised the Moscow city soviet for an ordinance prohibiting the sale of vodka in market stalls, but complained about its weak enforcement. ${ }^{80}$ In 1961 the Rostov city soviet's Trade Administration limited restaurants to serving no more than 100 grams of vodka to a customer and prohibited its sale in dining rooms and cafes, but left the sale of wine and brandy completely unregulated. ${ }^{81}$ As samples of apparently widespread provisions, one source cites the prohibition of the sale of vodka in fish, meat, fruit, vegetable, dairy, and dietetic stores, in all eating places (excluding restaurants) in railroad stations and airports, as well as before 10 A.M. and to minors. ${ }^{82}$ The volume of complaints indicates that many of these regulations are honored mainly in the breach.

The considerable income the state receives from alcohol, however, may limit how far it is willing to go to restrict trade. The collective volume Alcoholism: Path to Crime contains among its concluding proposals certain ones for the "furthest development" of sale restriction measures on "strong drink" and for a gradual substitution of some other source for the income the state now derives from alcohol. ${ }^{83}$ There is little evidence that much action has been taken on either proposal.

77. I. S. Sokolov, "O protivoalkogol'noi propagande v SSSR i v kapitalisticheskikh stranakh," Sovetskoe zdravookhranenie, 1961, no. 2, pp. 25-30.

78. See, for example, Vecherniaia Moskova, Sept. 20, 1963, p. 4.

79. See Komsomol'skaia pravda, Sept. 10, 1961, p. 4 (trans. in CDSP, Oct. 4, 1961, pp. 15-16).

80. Izvestiia, Mar. 2, 1958, p. 4 (trans. in CDSP, Apr. 9, 1958, p. 29).

81. Komsomol'skaia pravda, Sept. 10, 1961, p. 4 (trans. in CDSP, Oct. 4, 1961, pp. 15-16).

82. See Alkogolizm: Put' $k$ prestupleniiu, pp. 89-90.

83. Ibid., pp. $152-54$. 


\section{The Future}

The foregoing survey of popular values, official attitudes, and the measures employed to combat drunkenness and alcoholism in the USSR leads us to the question, What of the future? Is there any evidence that measures now in effect or recently proposed will affect the problem significantly? As economic conditions continue to improve over the nadir reached in the years immediately after World War II, one might expect a decline in purely "escapist" drinking. But the whole pattern of complaints about the drinking behavior of factory workers and kolkhozniks seems to reflect a stable "drinking culture," many elements of which are traceable, in both the urban and rural populations, to peasant life in the nineteenth century. ${ }^{84}$ That so much of this culture survived the Revolution and the migration of the population to the cities is not surprising. Studies of the drinking behavior of Irish, Jews, and Italians show that generally their respective high and low potentials for alcohol pathologies also survived large-scale immigration to the United States.

Thus many of the measures discussed seem destined for little success. "Antialcohol propaganda" reiterates the same appeals in each year's crop of books, pamphlets, and films, and seems as far as ever from gaining mass attention in an effective way. Segal is certainly correct that the identification of drinking with manliness and conviviality in so many minds is one of the major factors in the low effectiveness of the propaganda directed against alcohol, but the "scare tactics" the propagandists use in referring to the physical consequences of alcoholism are exactly the sort he warns against. ${ }^{85}$ The inertia evident in most of this pamphleteering suggests that the "formula" used now, ineffective as it may be, will endure.

What is true of antialcohol propaganda seems all the more true of attempts to enlist the "public" (with the possible exception of some women) in the struggle on any mass scale. Such "popular" social control mechanisms as the comrades' courts and people's volunteers (druzhiny), although they may enjoy public support in some of their dealings with petty "hooligans" and the like, have yet to make a large dent, apparently, in the problems within their provinces. Any All-Union Society for the Struggle with Alcoholism which depends on unpaid volunteers for its "mass" work will be likely to encounter

84. This applies especially to the patterns of "periodic carousal" on holidays (church or state-sponsored), and the tendency to celebrate with strong drink taken "straight," whether legally purchased or illegally distilled-all within the framework of a continuing state monopoly on legal distilling. For the earlier period see Geroid T. Robinson, Rural Russia Under the Old Régime (New York, 1932; reprinted 1967), pp. 252 and 259; also Stephen P. and Ethel Dunn, The Peasants of Central Russia (New York, 1967), p. 29.

85. Segal, Alkogolizm, pp. 545-46. 
the same problems as the comrades' courts and, more so, the druzhiny-"assignment" of personnel to duties under party or trade-union pressures rather than "volunteering," and a consequent lack of interest in and, wherever possible, avoidance of the work involved. Since the average citizen is less concerned about drunkenness than crime and directly "antisocial" behavior, there is little to be expected from such organizations, if established. ${ }^{86}$

Compulsory treatment in the institutions referred to earlier is aimed at the isolation and "cure" of those with serious drinking problems and antisocial behavior. It appears that the lines between the treatment for this category and for "garden variety" criminals (short of repeated offenders) are loosely drawn (with the exception of the medical treatment the former are to receive). Experiences with compulsory treatment in the past were not the kind that would inspire confidence. Whether longer sentences under the new legislation will prove more effective remains to be seen. "Punitive" approaches to problem drinkers are rarely successful, and it seems a vain hope that this one will be more effective than medical measures of a chemical or psychiatric variety. (With regard to the more strictly "medical" approaches, Segal notes that the average "cure" is "not long," and that in one-third of all cases "recidivism" occurs early.) ${ }^{87}$

One cannot say definitely that the Soviet alcohol problem is increasing. Perhaps it has "stabilized." However, the tone of government pronouncements and the language of antialcohol propaganda make it clear that it is not decreasing. As is true of crime and delinquency, the problem of alcoholism is not one that menaces the stability of Soviet society on the whole. But it does reflect the limited ability of a government never notably reluctant to intervene in the everyday lives of its citizens to modify widespread behavior patterns when those patterns are supported or tolerated by the mass of the people.

86. If, as Gertsenzon suggests (see note 3), a state coordinating body for the "struggle" is consolidated, some improvement in enforcement of existing trade regulations might be possible.

87. Segal, Alkogolizm, p. 533. 